\title{
KARAKTERISTIK BRIKET DAUN DAN BATANG TANAMAN NANAS MENGGUNAKAN PEREKAT ALAMI LATEKS
}

\author{
Rizky Tirta Adhiguna ${ }^{1)}$, Amin Rejo ${ }^{2)}$ \\ ${ }^{1,2}$ Program Studi Teknik Pertanian, Universitas Sriwijaya \\ Email: rizky_adhiguna@unsri.ac.id ${ }^{1)}$ \\ Nomor Telp: +62 85273343000 \\ Asal Negara: Indonesia
}

\begin{abstract}
ABSTRAK
Briket yang memanfaatkan bahan daun dan batang tanaman nanas merupakan sumber energi alternatif, yang terbarukan dan ramah lingkungan. Penelitian dilakukan untuk mengetahui karakteristik dari briket berbahan daun dan batang tanaman nanas menggunakan perekat alami lateks serta untuk mengetahui pengaruh penambahan perekat alami lateks terhadap parameter kadar air, abu, zat hilang pada suhu $950{ }^{\circ} \mathrm{C}$, kalor, dan laju pembakaran briket. Penelitian menggunakan rancangan acak lengkap, untuk faktor daun dan batang serta tingkat persentase perekat alami lateks 4\%, $8 \%$ dan 12\%. Data penelitian dianalisis menggunakan Analisis of Variance (ANOVA) dan Duncan's New Multiple Range Test (DNMRT) taraf 5\%. Penelitian menunjukkan perlakuan faktor bagian tanaman (daun dan batang) dan tingkat persentase perekat alami lateks berpengaruh nyata terhadap parameter dalam penelitian. Kadar air, abu, dan zat hilang suhu $950{ }^{\circ} \mathrm{C}$ untuk briket batang lebih tinggi dari briket daun, sedangkan kalor dan laju pembakaran briket daun lebih tinggi untuk setiap persentase perekat lateks. Nilai parameter (air, abu, kalor) sesuai SNI 01-6235-2000 adalah briket daun dengan perekat lateks 4\%, secara berturutturut $3,52 \pm 0,14 \%, 14,35 \pm 0,06 \%$, dan $5156 \pm 8,62 \mathrm{kalori} / \mathrm{gram}$.
\end{abstract}

Kata kunci: karakteristik, briket, daun, batang, nanas

\section{ABSTRACT}

Briquettes generated from pineapple plant waste leaves and stems can be utilized to provide a renewable and ecologically friendly alternative energy source. The study was conducted to evaluate the properties of briquettes and their effect on moisture content, ash content, volatile substance content at $950^{\circ} \mathrm{C}$, calorific value, and rate of briquette combustion. The study used a completely randomized design with treatments on different parts of the pineapple plant (leaves and stems), and natural latex adhesive was used in 4\%, 8\%, and 12\%. The data was examined using Analysis of Variance, and Duncan's New Multiple Range Test. The results revealed that briquettes made from pineapple waste with the addition of natural latex glue had a significant effect on the observed parameters. In this study, the value of moisture content, ash content, and the volatile substance content showed that the stem briquettes had a higher than leaf briquettes but had a lower calorific value and combustion rate. Leaf briquettes with $4 \%$ latex adhesive with a water content of $3.52 \pm 0.14 \%$, ash content of $14.35 \pm 0.06 \%$, and calorific value of 156 \pm 8.62 calories/gram met the quality standard of SNI 01-6235-2000.

\section{Keywords: properties, briquette, leaf, stem, pineapple.}

\section{PENDAHULUAN}

Nanas (Ananas comosus) merupakan salah satu komoditas yang cukup primadona untuk di produksi oleh petani dan usaha sektor pertanian di Indonesia. Badan Pusat Statistik Indonesia (2020) melaporkan bahwa sekitar 9,84\% produksi buahbuahan secara nasional bersumber dari usaha budidaya tanaman nanas. Umur produksi tanaman nanas dapat mencapai 2 tahun. Usaha budidaya tanaman nanas memberikan potensi limbah biomassa cukup tinggi yang dapat memberikan dampak kepada lingkungan. Bagian tanaman nanas yaitu daun dan batang termasuk dalam sumber limbah biomassa yang banyak dihasilkan dari usaha budidaya tanaman nanas. Setelah selesai produksi, umumnya petani menumpukkan daun dan batang tanaman nanas di lahan atau dibakar tanpa dimanfaatkan lebih lanjut.
Jumlah daun tanaman nanas yang dihasilkan saat usia produksi lebih dari 70 helai daun setiap tanaman (Hutabarat dan Sigalingging, 2019). Daun nanas memiliki bentuk memanjang dan sempit dengan ukuran panjang 120-150 cm dan lebar 5-7 cm. Daun nanas yang lebih tua memiliki ukuran lebih pendek dari ukuran daun muda dan menempati posisi di bawah daun muda pada batang tanaman. Tanaman nanas memiliki jumlah daun lebih dari 35 helai daun pada umur 12 bulan setelah tanam. Daun tanaman nanas tumbuh mengelilingi batang tanaman dari bawah ke atas. Bentuk daun nanas yang lanset dengan bentuk ujung daun yang runcing dan bentuk bulat di pangkal dengan permukaan licin dan memiliki duri baik secara merata di sekeliling daun maupun hanya berduri di ujung daun (Ardi, et al., 2019). Batang tanaman nanas rata-rata memiliki ukuran panjang 25$50 \mathrm{~cm}$. Tanaman nanas memiliki ukuran diameter 
batang 5-8 $\mathrm{cm}$ bagian pangkal dan mengecil di ujung dengan ukuran diameter $2-5 \mathrm{~cm}$. Jarak ruas tumbuh daun pada batang tanaman berkisar 1-10 mm (Bartholomew, et al., 2003).

Produksi briket dari bahan daun dan batang tanaman nanas adalah salah satu cara dalam memanfaatkan limbah biomassa dari usaha budidaya tanaman nanas untuk menghasilkan energi alternatif yang ramah lingkungan, lebih murah dan termasuk energi terbarukan. Briket sebagai bahan bakar padat bersifat organik dan memiliki dimensi relatif seragam dari hasil pengempaan (Wandi, et al., 2015). Briket dapat dibuat menggunakan teknologi sederhana menggunakan drum kiln dan alat pengempa untuk mencetak briket berbentuk silinder atau kotak. Keberadaan perekat dalam pembuatan briket dapat mempengaruhi mutu briket, baik jenis maupun jumlah perekatnya (Anizar, et al., 2020).

Perekat yang digunakan dalam pembuatan briket diantaranya lateks. Lateks perekat dari tanaman karet yang memiliki ketersediaan melimpah dan diproduksi secara massal. Lateks atau karet alami bersifat adhesif karena memiliki polimer polistirena yang mampu terikat menjadi rantai polimer. Penambahan bahan perekat pada briket dapat mengurangi tingkat kerusakan dan memperkecil poripori pada briket sehingga briket lebih padat (Jayanti et al. 2019).

Beberapa penelitian telah dilaporkan dalam memanfaatkan limbah daun tanaman untuk menghasilkan briket. Arif et al., (2012) melakukan penelitian besaran kalor briket dari daun kakao serta jati, hasil penelitian menunjukkan bahwa kalor briket daun kakao sebesar $4004 \mathrm{kal} / \mathrm{g}$ dengan variasi 3442$4004 \mathrm{kal} / \mathrm{g}$. Wandi et al., (2015) melakukan penelitian tentang briket dari pencampuran limbah daun kering dan serbuk kayu, hasil penelitian menunjukkan bahwa briket dengan rasio perbandingan daun kering dan serbuk kayu masingmasing $40 \mathrm{~g}: 20 \mathrm{~g}$ memiliki kualitas briket terbaik dengan nilai kalor sebesar $145320 \mathrm{~J}$ yang secara cepat mendidihkan air sebanyak $1 \mathrm{~kg}$. Rahmadani et al., (2017) melakukan penelitian tentang briket dengan memanfaatkan daun sawit dengan formulasi terbaik menggunakan persentase sagu sebesar 3\% dengan nilai kalor $51114 \mathrm{kal} / \mathrm{g}$.

Lebih lanjut penelitian tentang pemanfaatan batang tanaman dari kelapa sawit dan kayu laban sebagai bahan baku briket telah dilakukan oleh Kahariayadi et al., (2015), kalor maksimal 6377,67 $\mathrm{kal} / \mathrm{g}$ (40\% arang batang dan $60 \%$ arang kayu laban). Santy et al., (2019) melakukan penelitian briket dari batang singkong, dengan kalor tertinggi mencapai $7184 \mathrm{kal} / \mathrm{g}$ dengan perekat kotoran sapi.

Sulasri et al., (2014) melaporkan bahwa kadar air lateks alami berkisar antara 55-65 \%. Penelitian tentang perekat lateks atau karet alami yang digunakan sebagai bahan perekat dalam pembuatan briket telah dilaporkan oleh Syaukani et al., (2019), hasil penelitian melaporkan bahwa bahan perekat lateks yang meningkat berpengaruh terhadap penurunan kalor, karena kadar air semakin meningkat dengan meningkatnya jumlah perekat.

\section{METODE PENELITIAN}

Penelitian dilaksanakan pada bulan MaretJuni Tahun 2021 di Laboratorium Energi dan Bahan Mineral Provinsi Sumatera Selatan, dan Laboratorium Biosistem Jurusan Teknologi Pertanian Universitas Sriwijaya.

\subsection{Bahan dan Peralatan}

Penelitian berbahan limbah biomassa dari daun dan batang tanaman nanas dengan usia tanam 1 tahun, panjang dan lebar $5 \mathrm{~cm}$, dan lateks (getah karet). Alat terdiri dari furnace, bomb calorymeter, cawan porselin, kompor listrik, alat penggiling, timbangan analitik, alat pengempa hidrolik, gelas ukur, saringan ukuran 40 mesh dan oven.

\subsection{Pembuatan Arang Briket}

Pembuatan arang dari bahan baku daun dan batang tanaman nanas menggunakan metode Ritzada et al. (2021) menggunakan cawan porselin, alat furnace dengan suhu pembakaran $300{ }^{\circ} \mathrm{C}$ (1 jam). Hasil pembuatan arang selanjutnya dikecilkan ukuran menggunakan alat penggiling dan disaring menggunakan ayakan dengan ukuran 40 mesh.

\subsection{Pencampuran Perekat dan Arang Briket}

Serbuk arang daun dan batang tanaman nanas yang telah dikecilkan ukuran, kemudian ditimbang dengan masing-masing berat $100 \mathrm{~g}$ dengan perbandingan masing-masing perekat lateks $4 \%, 8 \%$ dan $12 \%$ dari total berat arang daun dan batang tanaman nanas.

\subsection{Pencetakan dan Pengeringan Briket}

Proses pencetakan briket menggunakan metode Musabbikhah et al., (2015) dengan alat pengempa dan bentuk cetak silinder. Tekanan alat pengempa sebesar $200 \mathrm{~kg} / \mathrm{cm}^{2}$ kemudian ditahan selama 5 menit untuk masing-masing bahan baku dari daun dan batang tanaman nanas. Briket daun dan batang dari tanaman nanas yang dihasilkan selanjutnya dikeringkan menggunakan oven dengan suhu pengeringan $50^{\circ} \mathrm{C}$ selama 2 hari.

\subsection{Pengujian Mutu Briket}

Pengujian karakteristik mutu briket dilakukan menggunakan metode dan kriteria SNI 01-6235-2000 yang terdiri dari berbagai parameter mutu untuk kedua briket daun dan batang dari tanaman nanas.

\subsection{Pengujian Laju Pembakaran}

Pengujian laju pembakaran menggunakan metode Jamilatun (2012), dengan menimbang sampel briket, selanjutnya kayu yang sudah dinyalakan apinya digunakan untuk membakar briket yang diletakkan diatas kawat kasa. Lama briket menyala 
hingga padam dihitung menggunakan stopwatch. Laju pembakaran (g/detik) diperoleh dari hasil perbandingan bobot sampel briket $(\mathrm{g})$ terhadap waktu pembakaran (detik).

\subsection{Analisa Data}

Data dari hasil pengukuran selanjutnya dilakukan Analisis of Variance (ANOVA) dan uji lanjut Duncan's New Multiple Range Test (DNMRT) pada taraf $5 \%$.

\section{HASIL DAN PEMBAHASAN}

\subsection{Kadar Air Briket}

Kadar air dari bahan baku daun dan batang tanaman nanas, diperoleh dari jumlah kandungan air yang dihasilkan oleh perekat, yaitu lateks. Rata-rata kadar air lateks yang digunakan dalam penelitian sebesar $62,84 \%$. Hasil pengukuran rata-rata dan analisis kadar air briket dari daun dan batang tanaman nanas dapat dilihat pada Gambar 1.

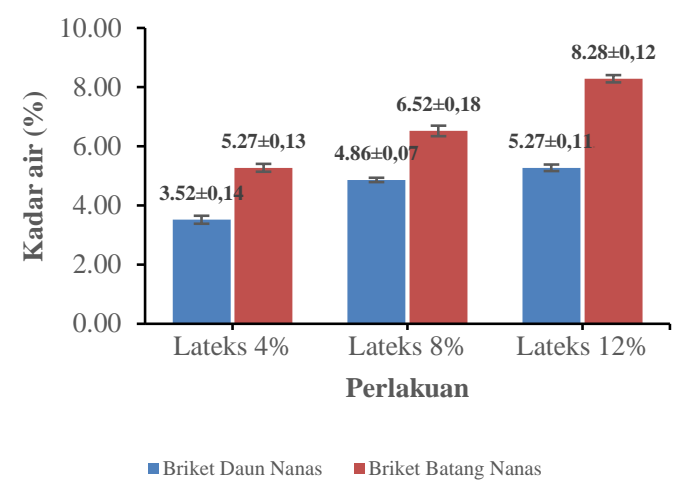

Gambar 1. Analisis kadar air briket dari daun dan batang tanaman nanas.

Briket daun dan batang dari tanaman nanas menghasilkan rataan nilai kadar air berbeda dari setiap tingkat persentase perekat lateks. Kadar air briket batang lebih tinggi untuk setiap tingkat persentase lateks $4 \%$, 8\% dan $12 \%$ dari kadar air briket daun. Kadar air briket batang tertinggi dengan tingkat persentase perekat lateks $12 \%$ sebesar $8,28 \pm 0,12 \%$, sedangkan terendah diperoleh briket daun melalui tingkat persentase lateks $4 \%$ sebesar $3,52 \pm 0,14 \%$.

Hasil penelitian memperlihatkan bahwa kandungan air pada kedua briket daun dan batang mengalami peningkatan dengan bertambahnya tingkat persentase perekat lateks. Kemudian hasil uji lanjut BNT menunjukkan bahwa perlakuan faktor bagian tanaman nanas (daun dan batang), faktor kandungan perekat $(4 \%, 8 \%$, dan $12 \%)$ dan interaksi antara kedua faktor berpengaruh nyata terhadap nilai kadar air briket pada taraf 5\%. Nilai kadar air menjelaskan sifat higroskopis briket dalam menyerap uap air dari udara lingkungan melalui pori-pori (Wandi et al., 2015)

Berdasarkan dari rataan nilai kadar air pada penelitian ini, briket yang tidak memenuhi batasan maksimal nilai kadar air sesuai standar mutu SNI 01-
6235-2000 sebesar 8\% adalah briket batang dari tanaman nanas untuk persentase perekat lateks $12 \%$ yaitu $8,28 \pm 0,12 \%$. Kandungan air yang tinggi pada briket dapat menyebabkan suhu pembakaran dan tingkat kemampuan penyalaan menjadi lebih rendah. Kadar air yang tinggi membutuhkan banyak kalor untuk menguapkan air dari dalam briket sehingga energi yang tersisa dalam briket menjadi rendah (Rahmadani et al., 2017).

\subsection{Kadar Abu Briket}

Kadar abu merupakan kandungan sisa dari hasil pembakaran briket yang tidak memiliki kadar karbon. Kadar abu juga menjelaskan besaran kandungan mineral dari masing-masing briket daun dan batang dari tanaman nanas yang tidak hilang selama pembakaran (Jayanti et al., 2019). Hasil pengukuran rata-rata dan analisis kadar abu briket daun dan batang dari tanaman nanas dapat dilihat pada Gambar 2.

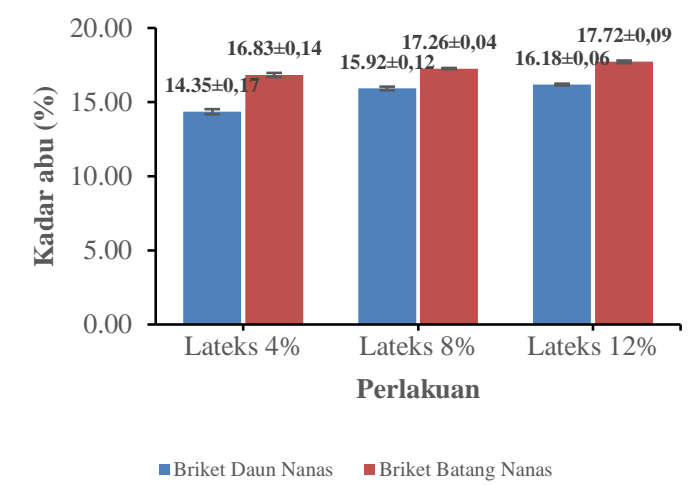

Gambar 2. Analisis kadar abu briket dari daun dan batang tanaman nanas.

Rataan nilai kadar abu briket daun lebih tinggi dibandingkan rataan nilai kadar abu dari briket batang dari tanaman nanas untuk setiap tingkat persentase perekat lateks $4 \%, 8 \%$ dan $12 \%$. Nilai kadar abu briket tertinggi diperoleh dari briket batang dari tanaman nanas dengan tingkat persentase perekat lateks $12 \%$ sebesar $17,72 \pm 0,14 \%$, sedangkan nilai kadar abu terendah diperoleh dari briket daun dengan tingkat persentase perekat lateks $4 \%$ sebesar $14,35 \pm 0,06 \%$.

Rataan nilai kadar abu kedua briket daun dan batang dari tanaman nanas mengalami peningkatan dengan bertambahnya tingkat persentase perekat lateks. Hasil uji lanjut BNT menunjukkan bahwa perlakuan faktor bagian tanaman nanas (daun dan batang), faktor kandungan perekat $(4 \%, 8 \%$, dan $12 \%$ ) serta interaksinya memberikan pengaruh nyata nilai abu briket pada taraf $5 \%$.

Berdasarkan dari rataan nilai kadar abu pada penelitian ini, briket yang memenuhi batasan maksimal nilai kadar abu sesuai standar mutu SNI 01-6235-2000 sebesar 15\% adalah briket daun dari tanaman nanas untuk persentase perekat lateks $4 \%$. Kahariayadi et al., (2015) menjelaskan bahwa kualitas briket semakin rendah dengan semakin 
tingginya nilai kadar abu karena nilai kalor yang dihasilkan menjadi rendah. Ritzada et al., (2021) menjelaskan bahwa unsur utama abu adalah silika yang mampu menurunkan nilai kalor briket. Penelitian ini juga memperoleh rataan nilai kadar abu perekat lateks yang digunakan sebesar 1,48\%. Lebih lanjut, Rahmadani et al., (2017) menjelaskan bahwa konsentrasi bahan arang yang lebih tinggi menyebabkan tingginya nilai kadar abu briket.

\subsection{Kadar Zat Yang Hilang Pada Suhu $950{ }^{\circ} \mathrm{C}$}

Proses dekomposisi berbagai senyawa melalui proses pembakaran suhu $950{ }^{\circ} \mathrm{C}$ menyebabkan zatzat yang bersifat volatil pada briket menguap ke udara atau lingkungan. Nilai yang tinggi zat hilang berdampak pada rendahnya nilai kalor (Rahmadani et al., 2017). Hasil pengukuran rata-rata dan analisis nilai kadar zat hilang pada briket daun dan batang dari tanaman nanas dapat dilihat pada Gambar 3.

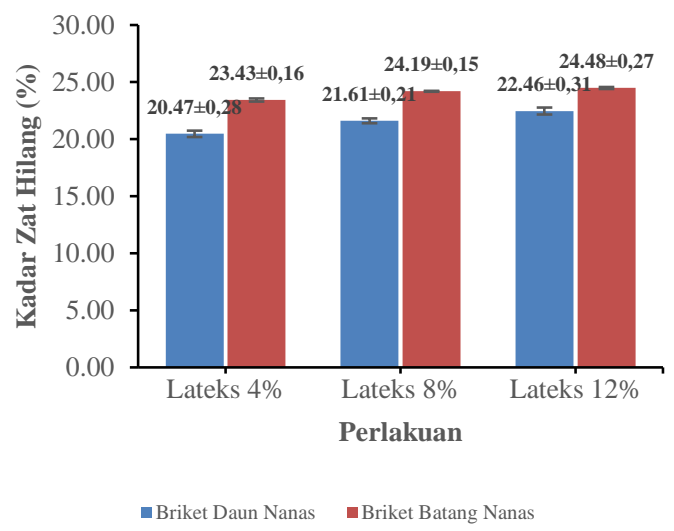

Gambar 3. Analisis kadar zat hilang briket dari daun dan batang tanaman nanas.

Briket daun dan batang dari tanaman nanas menghasilkan rataan nilai kadar zat yang hilang berbeda untuk setiap tingkat persentase perekat lateks. Zat yang hilang pada briket batang lebih tinggi untuk setiap tingkat persentase perekat lateks $4 \%, 8 \%$ dan $12 \%$ dari kadar air briket daun. Persentase zat yang hilang paling tinggi briket batang dengan tingkat persentase perekat lateks $12 \%$ sebesar $24,48 \pm 0,27 \%$ dan paling rendah briket daun untuk tingkat persentase perekat lateks $4 \%$ sebesar $20,47 \pm 0,28 \%$.

Hasil penelitian memperlihatkan bahwa kadar zat hilang pada kedua briket daun dan batang mengalami peningkatan dengan bertambahnya tingkat persentase perekat lateks. Kemudian hasil uji lanjut BNT menunjukkan bahwa perlakuan faktor bagian tanaman nanas (daun dan batang), faktor kandungan perekat $(4 \%, 8 \%$, dan $12 \%)$ dan interaksi antara faktor memberikan pengaruh nyata terhadap kadar zat hilang briket taraf 5\%.

Berdasarkan dari rataan nilai kadar zat yang hilang pada suhu $950{ }^{\circ} \mathrm{C}$ dalam penelitian ini, keseluruhan perlakuan tidak memenuhi SNI 016235-2000 sebesar $8 \%$.

\subsection{Nilai Kalor}

Besaran kalor briket dapat dipengaruhi tingginya kadar air dan abu sehingga kalor pada briket menjadi rendah (Masthura 2019). Lebih lanjut, kandungan kadar karbon terikat berpengaruh, dimana jumlah karbon dipengaruhi abu dan zat yang hilang (Kahariayadi et al., 2015). Hasil pengukuran rata-rata nilai kalor pada briket daun dan batang dari tanaman nanas dapat dilihat pada Gambar 4.

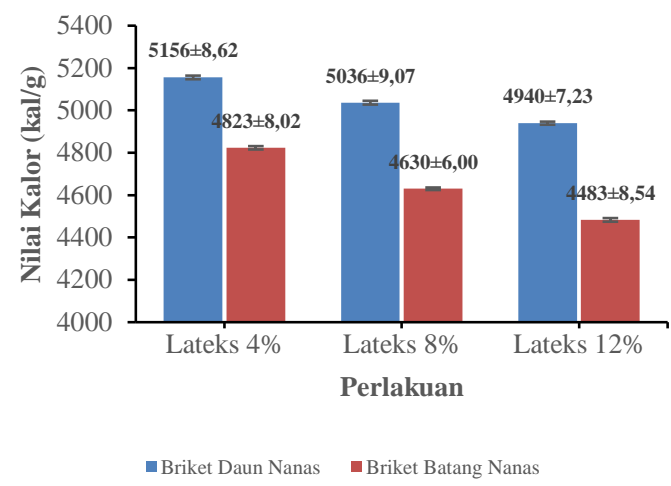

Gambar 4. Analisis nilai kalor briket dari daun dan batang tanaman nanas.

Briket daun dan batang dari tanaman nanas menghasilkan rataan nilai kalor berbeda untuk setiap tingkat persentase perekat lateks. Nilai kalor pada briket batang lebih rendah untuk setiap tingkat persentase perekat lateks $4 \%, 8 \%$ dan $12 \%$ dari kadar air briket daun. Briket daun memiliki kalor paling tinggi dengan tingkat persentase lateks $4 \%$ sebesar $5156 \pm 8,62 \mathrm{kal} / \mathrm{g}$ dan kadar air briket terendah diperoleh pada briket batang dengan tingkat persentase perekat lateks $12 \%$ sebesar $4483 \pm 8,54 \%$.

Hasil menjelaskan kalor kedua briket daun dan batang mengalami penurunan dengan bertambahnya tingkat persentase perekat lateks. Kemudian hasil uji lanjut BNT menunjukkan bahwa perlakuan faktor bagian tanaman nanas (daun dan batang), faktor kandungan perekat $(4 \%, 8 \%$, dan $12 \%)$ serta interaksinya secara nyata memberikan pengaruh jumlah kalor briket pada taraf $5 \%$. Berdasarkan dari rataan kalor, briket daun memenuhi batasan minimal di SNI 01-6235-2000 sebesar 5000 kalori/gram adalah pada briket daun dari tanaman nanas untuk persentase perekat lateks secara berturutturut $4 \%$ dan $8 \%$ yaitu $5156 \pm 8,62 \mathrm{kal} / \mathrm{g}$ dan $5036 \pm 9,07 \mathrm{kal} / \mathrm{g}$.

\subsection{Laju Pembakaran}

Efektifitas dari briket sebagai sumber energi terbarukan dapat diketahui melalui pengukuran laju pembakaran (Almu, et al., 2014). Lebih lanjut Masthura (2019) menjelaskan bahwa laju pembakaran dapat memberikan pengaruh terhadap nilai kalor pada briket. Hasil pengukuran rata-rata dan analisis nilai laju pembakaran pada briket daun dan batang dari tanaman nanas dapat dilihat pada Gambar 5. 


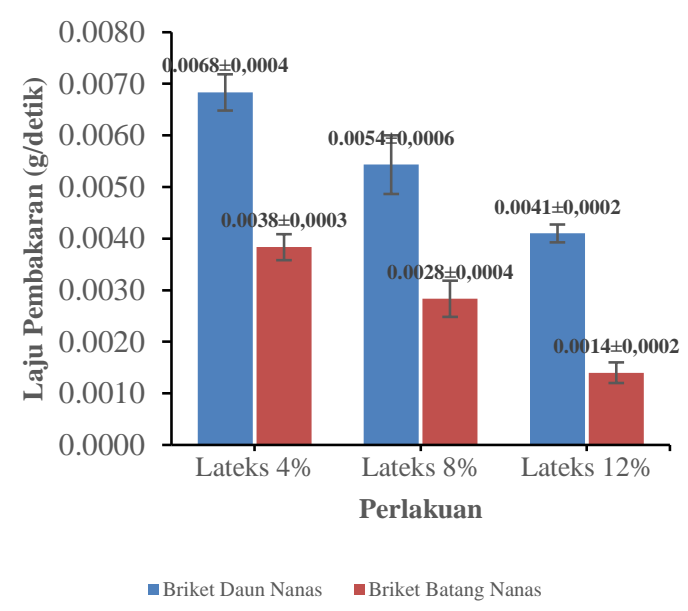

Gambar 5. Analisis laju pembakaran briket dari daun dan batang tanaman nanas.

Hasil penelitian menunjukkan bahwa rataan laju pembakaran briket daun lebih tinggi untuk setiap tingkat persentase perekat lateks $4 \%, 8 \%$ dan $12 \%$ dari laju pembakaran briket batang tanaman nanas. Nilai rataan laju pembakaran tertinggi pada briket daun dengan tingkat persentase perekat lateks $4 \%$ sebesar 0,0068 $\pm 0,0004 \mathrm{~g} /$ detik dan laju pembakaran briket terendah diperoleh pada briket batang dengan tingkat persentase perekat lateks $12 \%$ sebesar 0,0014 $\pm 0,0002 \mathrm{~g} /$ detik.

Lebih lanjut hasil penelitian juga menunjukkan bahwa laju pembakaran pada kedua briket daun dan batang mengalami peningkatan dengan bertambahnya tingkat persentase perekat lateks. Kemudian hasil uji lanjut BNT menunjukkan bahwa perlakuan faktor bagian tanaman nanas (daun dan batang), faktor kandungan perekat $(4 \%, 8 \%$, dan $12 \%$ ) dan interaksi secara nyata memberikan pengaruh terhadap laju pembakaran briket pada taraf $5 \%$.

\section{KESIMPULAN DAN SARAN}

Perlakuan faktor bagian tanaman nanas (daun dan batang) dan tingkat persentase perekat alami lateks berpengaruh nyata terhadap parameter mutu dan laju pembakaran kadar air, kadar abu, kadar zat yang hilang pada suhu $950{ }^{\circ} \mathrm{C}$, nilai kalor dan laju pembakaran briket; kadar air, abu, dan zat hilang pada suhu $950{ }^{\circ} \mathrm{C}$ pada briket batang lebih tinggi dari briket daun untuk setiap tingkat persentase perekat lateks $4 \%, 8 \%$ dan $12 \%$, sedangkan kalor maupun laju pembakaran briket daun tertinggi untuk setiap persentase perekat lateks $4 \%, 8 \%$ dan $12 \%$; rataan nilai kadar air, abu, dan kalor yang memenuhi kriteria SNI 01-6235-2000 adalah briket daun untuk persentase perekat lateks $4 \%$ secara berturut-turut $3,52 \pm 0,14 \%, \quad 14,35 \pm 0,06 \%$, dan $5156 \pm 8,62$ kalori/gram.

Saran dalam penelitian ini adalah menggunakan jenis perekat alami yang berbeda seperti tepung tapioka dan sagu.

\section{DAFTAR PUSTAKA}

Almu, M. Afif, S. Syahrul, dan Y. A. Padang. 2014. "Analisa Nilai Kalor Dan Laju Pembakaran Pada Briket Campuran Biji Nyamplung (Calophyllm Inophyllum) Dan Abu Sekam Padi." Dinamika Teknik Mesin 4(2):117-22.

Anizar, H., E. Sribudiani, dan S. Somadona. 2020. "Pengaruh Bahan Perekat Tapioka Dan Sagu Terhadap Kualitas Briket Arang Kulit Buah Nipah." Perennial 16(1):11-17.

Ardi, J., M. Akrinisa, dan M. Arpah. 2019. "Keragaman Morfologi Tanaman Nanas (Ananas Comosus (L) Merr) Di Kabupaten Indragiri Hilir." Jurnal Agro Indragiri 4(1):3438.

Arif, E., L. Salam, dan B. Fredy. 2012. "Briket Daun Kering Sebagai Sumber Energi Alternatif ( Dry Leaves Briquettes As An Alternative Energy Source )." Pp. 507-13 in Proceeding Seminar Nasional Tahunan Teknik Mesin XI (SNTTM XI) \& Thermofluid IV Universitas Gadjah Mada (UGM). Yogyakarta.

Badan Pusat Statistik Indonesia. 2020. Statistik Indonesia Tahun 2020. Vol. 1101001. BPSStatistics Indonesia.

Bartholomew, D., R. Paull, and K. Rohrbach. 2003. The Pineapple: Botany, Production, and Uses. New York: CABI Publishing.

Hutabarat, E., dan R. Sigalingging. 2019. "Pemanfaatan Limbah Serat Daun Nanas (Ananas Comosus) Sebagai Tali Serat Alami." Jurnal Rekayasa Pangan Dan Pertanian 6(4):807-12.

Jamilatun, S. 2012. "Sifat-Sifat Penyalaan Dan Pembakaran Briket Biomassa, Briket Batubara Dan Arang Kayu." Jurnal Rekayasa Proses 2(2):37-40.

Jayanti, A., A. Adriani, M. Kristiani, dan A. H. B. Hapsani. 2019. "Sebagai Bahan Baku Dalam Pembuatan Biobriket. Politeknik Pembangunan Pertanian: Sumatera Utara." Jurnal Agrica Ekstensia 14(1):1-9.

Kahariayadi, A., D. Setyawati, Nurhaida, F. Diba, dan E. Roslinda. 2015. "Kualitas Arang Briket Berdasarkan Persentase Arang Batang Kelapa Sawit (Elaeis Guineensis Jacq) Dan Arang Kayu Laban (Vitex Pubescens Vahl)." Hutan Lestari 3(4):561-68.

Masthura, M. 2019. “Analisis Fisis dan Laju Pembakaran Briket Bioarang Dari Bahan Pelepah Pisang." Elkawnie 5(1):58.

Musabbikhah, M., H. Saptoadi, S. Subarmono, dan M. A. Wibisono. 2015. "Optimasi Proses Pembuatan Briket Biomassa Menggunakan Metode Taguchi Guna Memenuhi Kebutuhan Bahan Bakar Alternatif yang Ramah Lingkungan (Optimization of Biomass Briquettes Production Process Using Taguchi Method)." Jurnal Manusia Dan Lingkungan 
22(1):121.

Rahmadani, F. Hamzah, dan F. H. Hamzah. 2017. "Pembuatan Briket Arang Daun Kelapa Sawit (Elaeis Guineensis Jacq.) Dengan Perekat Pati Sagu (Metroxylon Sago Rott.)." Jurnal Online Mahasiswa (JOM) Bidang Pertanian 4(12 (152)):1-11.

Ritzada, I. P. D. Putra, N. L. Yulianti, dan I. B. P. Gunadnya. 2021. "Karakteristik Briket Biomassa Dengan Variasi Geometri Dan Jenis Bahan Baku Yang Berbeda Characteristics." Jurnal Beta (Biosistem Dan Teknik Pertanian Program) 9(2):130-37.

Santy, K. G., O. Y. Belak, T. Iskandar, dan S. P. Abrina. 2019. "Proses Pembuatan Briket Arang Dari Limbah Batang Singkong Dengan Menggunakan Perekat Organik." 2:1-8.

Saukani, M., R. Setyono, dan I. Trianiza. 2019. "Pengaruh Jumlah Perekat Karet Terhadap Kualitas Briket Cangkang Sawit." Jurnal Fisika FLUX 1(1):159.

Sulasri, M. B. Malino, dan B. P. Lapanporo. 2014. "Penentuan Kadar Kering Karet (K3) Dan Pengukuran Konstanta Dielektrik Lateks." Prisma Fisika II(1):11-14.

Wandi, A., S. Harri, dan Askin. 2015. "Pemanfaatan Limbah Daun Kering Menjadi Briket Untuk Bahan Bakar Tungku." Berkala Ilmiah Pertanian 1(1):1-6. 